OPEN ACCESS

Edited by:

Matthias E. Kaestner,

Helmholtz-Zentrum für

Umweltforschung (UFZ), Germany

Reviewed by:

Binbin Liu,

Centre of Agricultural Resources

Research (CAS), China

Gwenaël Imfeld,

Centre National de la Recherche

Scientifique (CNRS), France

*Correspondence:

Jinshui Wu

jswu@isa.ac.cn

Xuliang Zhuang

xlzhuang@rcees.ac.cn

tThese authors have contributed equally to this work.

Specialty section:

This article was submitted to Microbiotechnology, Ecotoxicology

and Bioremediation,

a section of the journal

Frontiers in Microbiology

Received: 24 April 2017

Accepted: 21 September 2017

Published: 06 October 2017

Citation:

Sun H, LiU F, Xu S, Wu S,

Zhuang G, Deng Y, Wu J and

Zhuang X (2017) Myriophyllum aquaticum Constructed Wetland

Effectively Removes Nitrogen in Swine Wastewater. Front. Microbiol. 8:1932. doi: 10.3389/fmicb.2017.01932

\section{Myriophyllum aquaticum Constructed Wetland Effectively Removes Nitrogen in Swine Wastewater}

\author{
Haishu Sun ${ }^{1,2 \dagger}$, Feng Liu ${ }^{3+}$, Shengjun $X u^{1,2}$, Shanghua $W u^{1,2}$, Guoqiang Zhuang ${ }^{1,2}$, \\ Ye Deng ${ }^{1,2}$, Jinshui $\mathrm{Wu}^{3 *}$ and Xuliang Zhuang ${ }^{1,2 *}$
}

${ }^{1}$ Key Laboratory of Environmental Biotechnology, Research Center for Eco-Environmental Sciences, Chinese Academy of Sciences, Beijing, China, ${ }^{2}$ College of Resources and Environment, University of Chinese Academy of Sciences, Beijing, China, ${ }^{3}$ Key Laboratory of Agro-ecological Processes in Subtropical Regions, Institute of Subtropical Agriculture, Chinese Academy of Sciences, Changsha, China

Removal of nitrogen $(\mathrm{N})$ is a critical aspect in the functioning of constructed wetlands (CWs), and the $\mathrm{N}$ treatment in CWs depends largely on the presence and activity of macrophytes and microorganisms. However, the effects of plants on microorganisms responsible for $\mathrm{N}$ removal are poorly understood. In this study, a three-stage surface flow CW was constructed in a pilot-scale within monospecies stands of Myriophyllum aquaticum to treat swine wastewater. Steady-state conditions were achieved throughout the 600-day operating period, and a high (98.3\%) average ammonia removal efficiency under a $\mathrm{N}$ loading rate of $9 \mathrm{~kg} \mathrm{ha}^{-1} \mathrm{~d}^{-1}$ was observed. To determine whether this high efficiency was associated with the performance of active microbes, the abundance, structure, and interactions of microbial community were compared in the unvegetated and vegetated samples. Real-time quantitative polymerase chain reactions showed the abundances of nitrifying genes (archaeal and bacterial amoA) and denitrifying genes (nirS, nirK, and nos Z) were increased significantly by $M$. aquaticum in the sediments, and the strongest effects were observed for the archaeal amoA (218-fold) and nirS genes (4620-fold). High-throughput sequencing of microbial $16 \mathrm{~S}$ rRNA gene amplicons showed that $M$. aquaticum greatly changed the microbial community, and ammonium oxidizers (Nitrosospira and Nitrososphaera), nitrite-oxidizing bacteria (Nitrospira), and abundant denitrifiers including Rhodoplanes, Bradyrhizobium, and Hyphomicrobium, were enriched significantly in the sediments. The results of a canonical correspondence analysis and Mantle tests indicated that $M$. aquaticum may shift the sediment microbial community by changing the sediment chemical properties. The enriched nitrifiers and denitrifiers were distributed widely in the vegetated sediments, showing positive ecological associations among themselves and other bacteria based on phylogenetic molecular ecological networks.

Keywords: constructed wetlands, Myriophyllum aquaticum, nitrifiers, denitrifiers, community size, community structure, community interactions 


\section{INTRODUCTION}

Water pollution caused by excessive inputs of nutrients from non-point sources is regarded as a serious problem worldwide. According to China's first pollution survey, the discharge of phosphorus and nitrogen $(\mathrm{N})$ from agriculture accounted for 67 and 57\%, respectively, of the total emission loads (Ministry of Environmental Protection, National Bureau of Statistics of China, Ministry of Agriculture, 2010), thereby threatening water quality and human health (Beman et al., 2005). Constructed wetlands (CWs) have been developed as a sustainable technology for diffuse or non-point $\mathrm{N}$ pollution of water sources because of their technical feasibility, ecological benefits, and economic advantages (Cronk, 1996; Vymazal, 2011). An important part of the treatment in CWs is attributable to the presence and activity of macrophytes and microorganisms, although until recently the microbial ecology of wetlands has remained relatively uncharacterized. The relative importance of the interactions between the plants and microorganisms responsible for $\mathrm{N}$ removal are also poorly understood (Stottmeister et al., 2003).

Wetland macrophytes rooting in anoxic sediments maintain aerobic root respiration via internal oxygen transport through aerenchyma tissue. An excess of oxygen leaking from the roots (known as radial oxygen loss) results in an oxidized rhizosphere (Vartapetian and Jackson, 1997). Oxygen release from the roots of macrophyte species such as Littorella uniflora, Lobelia dortmanna, and Glyceria maxima stimulates nitrification in the rhizosphere compared with that in unvegetated sediment (Bodelier et al., 1996; Petersen and Jensen, 1997; Ottosen et al., 1999). It is generally accepted that plants promote denitrification because they consume oxygen, thereby increasing the anaerobic volume of the soil. Higher carbon availability through root exudation and litter deposition is another important factor that stimulates denitrification (Philippot et al., 2013). Unraveling the plants that affect microbial guilds involved in $\mathrm{N}$ cycling has great potential for designing CWs to optimize and compartmentalize the nitrification and denitrification (Ruiz-Rueda et al., 2009).

It is argued that plants alter physicochemical factors, such as the oxygen level, $\mathrm{pH}$, and carbon and $\mathrm{N}$ availability, which, in turn, influence the activity, diversity, and abundance of nitrifiers and denitrifiers, although few studies have reported quantitative evidences of these plant-microbe interactions in CWs (Philippot et al., 2013). Recently, several studies, many of which used culture-independent techniques, characterized microbial populations in laboratory-scale units and full-scale CWs under specific conditions (Dong and Reddy, 2010; He et al., 2016; Pelissari et al., 2017). However, the effect of macrophytes on the abundance and structure of microbial communities involved in $\mathrm{N}$ removal have not been well studied in CWs (Ruiz-Rueda et al., 2009). In contrast, plants have been shown to induce and stimulate specific microorganisms and create well-defined microbial communities that are involved in nitrification and denitrification in terrestrial soils (Philippot et al., 2002; Patra et al., 2006).

In this study, we designed a three-stage surface-flow $\mathrm{CW}$ in pilot-scale to treat high-strength swine wastewater. Macrophytes from a genus known to have the ability to create an oxidized rhizosphere and release organic carbon (Myriophyllum aquaticum) (Karjalainen et al., 2001; Laskov et al., 2006) were included. We also demonstrated previously that $M$. aquaticum is able to tolerate high-strength swine wastewater and effectively remove $\mathrm{N}$ from polluted waters in laboratory scale tests (Liu et al., 2016). We hypothesized that (i) the macrophytes would shift the structures of microbial communities in both water and sediment and (ii) the microorganisms responsible for $\mathrm{N}$ cyclings have been largely enhanced in vegetated condition. To test these hypotheses, high-throughput sequencing of the 16S rRNA gene was conducted to analyze the bacterial communities' responses to the macrophytes. In addition, real-time quantitative polymerase chain reaction ( $\mathrm{qPCR}$ ) analyses were conducted to determine the effects of the macrophytes on absolute abundance of nitrifying (archaeal and bacterial $a m o A$ ) and denitrifying (nirS, nirK, nos $Z$ ) genes. Furthermore, the correlations between bacteria and environmental factors and interactions among bacteria were determined.

\section{MATERIALS AND METHODS}

\section{Experimental Setup and Operation Mode}

The experiment was conducted at the Jinjing Catchment, Changsha, Hunan Province, China $\left(28^{\circ} 30^{\prime} \mathrm{N}, 113^{\circ} 18^{\prime} \mathrm{E}\right)$. This site has a subtropical monsoon climate with an annual average rainfall of $1330 \mathrm{~mm}$ and an annual average temperature of $17.5^{\circ} \mathrm{C}$. A surface-flow CW was established in March 2014, three cells were set up in parallel (three replicates). Each cell was divided into three identical segments (length, $5 \mathrm{~m}$; width, $2 \mathrm{~m}$; and water depth, $0.2 \mathrm{~m}$ ), named CW1, CW2, and CW3 (Supplementary Figure 1). M. aquaticum was planted on the wetland surface at an initial density of $3 \mathrm{~kg} \mathrm{~m}^{-2}$. The cell without planting the $M$. aquaticum was performed as the control. The influents from a storage tank and a fresh water tank were mixed in a settling pond installed in front of the CW, and the effluent of the CW was applied to the land. The characteristics of the swine wastewater are listed in Supplementary Table 1. Each cell was operated in an intermittent flow regime with a total of $0.18 \mathrm{~m}^{3} \mathrm{~d}^{-1}$ wastewater, and the hydraulic retention time was 11 days in each segment.

\section{Sample Collection}

Water samples were collected two or three times per month and were analyzed immediately at the laboratory. The dissolved oxygen (DO) and $\mathrm{pH}$ were measured in the field by a multi-parameters water quality monitoring instrument $(\mathrm{HACH}$, HQ30D, United States). Chemical oxygen demand (COD) was measured by a standard potassium dichromate titration method (Federation and Association, 2005). $\mathrm{NH}_{4}^{+}-\mathrm{N}, \mathrm{NO}_{2}^{-}-\mathrm{N}$, $\mathrm{NO}_{3}^{-}-\mathrm{N}$, and total $\mathrm{N}(\mathrm{TN})$ concentrations were measured by a continuous flow analyzer (AA3; Seal Analytical, Norderstedt, Germany). Microbial samples were sampled at $24 \pm 2^{\circ} \mathrm{C}$ during the stable operation periods. Water $(0-5 \mathrm{~cm}$ depth) and sediment $(0-5 \mathrm{~cm}$ depth) samples were taken in the second segment of the CW (CW2, 5-10 m from the inlets), which exhibited the highest $\mathrm{N}$ removal efficiency during the monitoring period. In September 2015, sediment cores were taken in 10 replicates 
from within monospecies of M. aquaticum and from unvegetated sediment for molecular analysis. Unvegetated sediment samples were obtained from the upper $5 \mathrm{~cm}$, which included the oxicanoxic interface. Vegetated sediment samples were obtained from all over the root zone by shaking off sediment that adhered to the roots. All the samples were stored in an ice cooler and brought back to our laboratory. The water samples were filtered onto a $0.22-\mu \mathrm{m}$ cellulose membrane, and the sediments samples were freeze-dried. Samples for DNA extraction were stored at $-80^{\circ} \mathrm{C}$ until use.

\section{DNA Extraction and qPCR}

Total DNA were extracted using the FastDNA SPIN Kit for Soil (MP Biomedical, Santa Ana, CA, United States) according to the manufacturer's protocol and then it was visualized using $1 \%$ agarose gel electrophoresis and stored at $-80^{\circ} \mathrm{C}$ until use.

Quantification of V4 region of the rrs gene, which encodes the $16 \mathrm{~S}$ rRNA, archaeal and bacterial amoA, nirK, nirs, and nos $Z$, were performed on a real-time PCR system (Bio-Rad, Hercules, CA, United States) using SYBR green as a fluorescent dye. The thermal cycling conditions and primers used for each reaction are described in Supplementary Table 2. Gene copy numbers in unknown samples were determined based on standard curves obtained from 10-fold serial dilutions of plasmids containing the target genes. The employed results with correlation coefficient and amplification efficiency were greater than 0.98 and $98 \%$, respectively. All samples were run on an agarose gel after the reaction to confirm the size of amplicons, and the specificity of the amplification products was confirmed by a melting curve analysis.

\section{PCR Amplification, Product Purification, and MiSeq Sequencing}

The V4 region of the bacterial $16 \mathrm{~S}$ rRNA gene was amplified using the primers 515F (5'-GTGCCAGCMGCCGCGGTAA-3') and 806R ( $5^{\prime}$-GGACTACHVGGGTWTCTAAT-3') (Caporaso et al., 2012). Each pair of primers used to amplify a certain water or sediment sample was barcoded with a sample-identifying 12base barcode on both the forward and reverse primers. The $50 \mu \mathrm{L}$ reaction system contained $20-30 \mathrm{ng}$ of DNA, $1.5 \mu \mathrm{L}$ of each primer (at a final concentration of $0.3 \mu \mathrm{M}$ ), and $25 \mu \mathrm{L}$ of Premix Ex Taq (TaKaRa, Dalian, China). The PCR conditions, performed in a PCR instrument (Eastwin, China), consisted of an initial denaturation step at $94^{\circ} \mathrm{C}$ for $1 \mathrm{~min}$, followed by 30 cycles at $94^{\circ} \mathrm{C}$ for $20 \mathrm{~s}, 57^{\circ} \mathrm{C}$ for $25 \mathrm{~s}$ and $72^{\circ} \mathrm{C}$ for $30 \mathrm{~s}$, and a final extension step at $72^{\circ} \mathrm{C}$ for $10 \mathrm{~min}$. The PCR amplicons were purified with the Gel Extraction Kit (D2500-02, Omega BioTek, Norcross, GA, United States), and DNA concentrations were quantified by a spectrophotometer (NanoDrop Technologies, Wilmington, DE, United States). True positive amplicons were combined equally, and a DNA library was obtained according to the MiSeq Reagent Kit Preparation Guide (Illumina, San Diego, CA, United States), and then the DNA library was sequenced using the Illumina MiSeq platform according to the manufacturer's instructions. All the raw sequences have been deposited into NCBI Short Read Archive (SRA) with accession no. SRP095281.

After assigning each sequence to its sample according to its barcode, allowing up to one mismatch, a total of 675,089 reads from both ends were obtained as a partitioned run for the 40 samples. Paired-end reads of sufficient length (those with at least a $30 \mathrm{bp}$ overlap) were combined into full-length sequences with targeting $253 \mathrm{bp}$ as average fragment length by FLASH (Magoč and Salzberg, 2011). Thereafter, quality trimming was performed using Btrim with a quality score of 20 as cutoff and 5 as window size (Kong, 2011). After removing the sequences with ambiguous bases, the sequences with lengths out of 245-260 bp were removed. Thereafter, UPARSE program (Edgar, 2013) was used to remove the chimeras and classify the sequences into operational taxonomy units (OTUs) at the 97\% similarity level. The taxonomic annotation of individual OTUs was performed through Ribosomal Database Project (RDP) classifier (Wang et al., 2007) with a minimal 50\% confidence score. Finally, random re-sampling was performed with 10,000 sequences per sample, and this resampled OTU summary table was used for further statistical analysis (Supplementary Data Sheet 2).

\section{Statistical Analysis}

One-way analysis of variance (ANOVA) followed by StudentNewman-Keuls test was used to check for quantitative differences between treatments using Statistics for Windows version 20.0 (IBM Corp., Armonk, NY, United States). The dataset generated by $16 \mathrm{~S}$ rRNA gene sequencing was further analyzed with all of the following statistical methods. (1) $\alpha$-diversity comparison analysis was performed using $\mathrm{R}$ vegan package. (2) Comparison tests between two groups were based on unpaired Student's t-test in Excel software. (3) The canonical correspondence analysis (CCA) was used to evaluate the linkages compositions and environmental factors (Legendre and Legendre, 2012). To select environmental factors in the CCA modeling, we used variation inflation factors to examine whether the variance of the canonical coefficients was inflated by the presence of correlations with other attributes. If a factor had a variation inflation factor value greater than 20 , we deemed it to be affected by other attributes and consequently removed it from the CCA biplot (Yang et al., 2014). Multivariate testing, based on 999 Monte Carlo permutations, confirmed the significance of the two canonical axes $(p \leq 0.001)$. The importance of the environmental attributes was verified by Mantel tests with 999 permutations based on their significant correlation $(p \leq 0.001)$. (4) Phylogenetic molecular ecological networks (pMENs) were constructed by regularly a random matrix theory (RMT)-based interface approach to elucidate the microbial interactions in the sediments and water with and without $M$. aquaticum. pMENs were generated based on a resampled OTU table at Molecular Ecological Network Analysis Pipeline (Zhou et al., 2010, 2011; Deng et al., 2012) ${ }^{1}$.

\footnotetext{
${ }^{1}$ http://ieg2.ou.edu/MENA/
} 

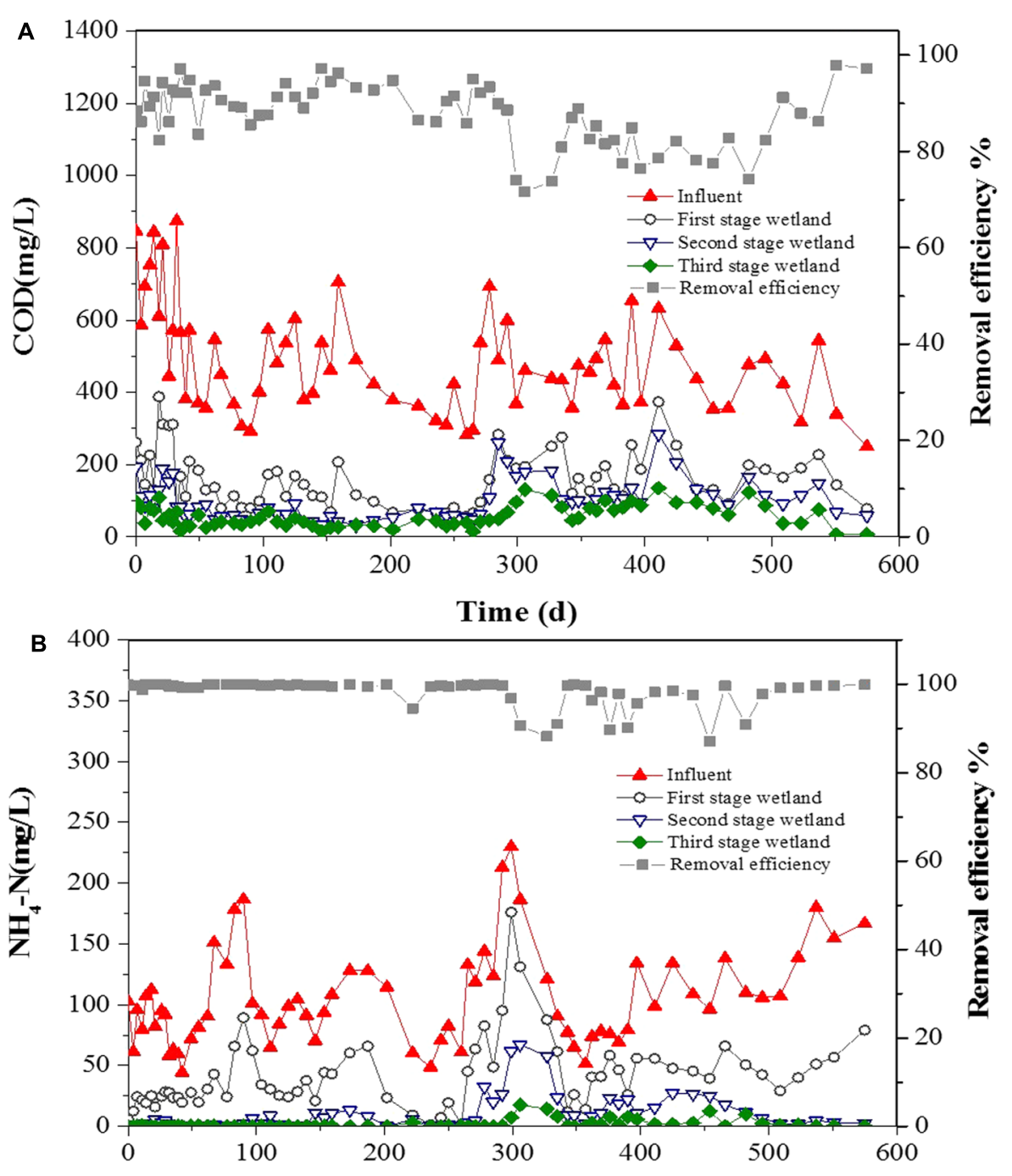

Time (d)

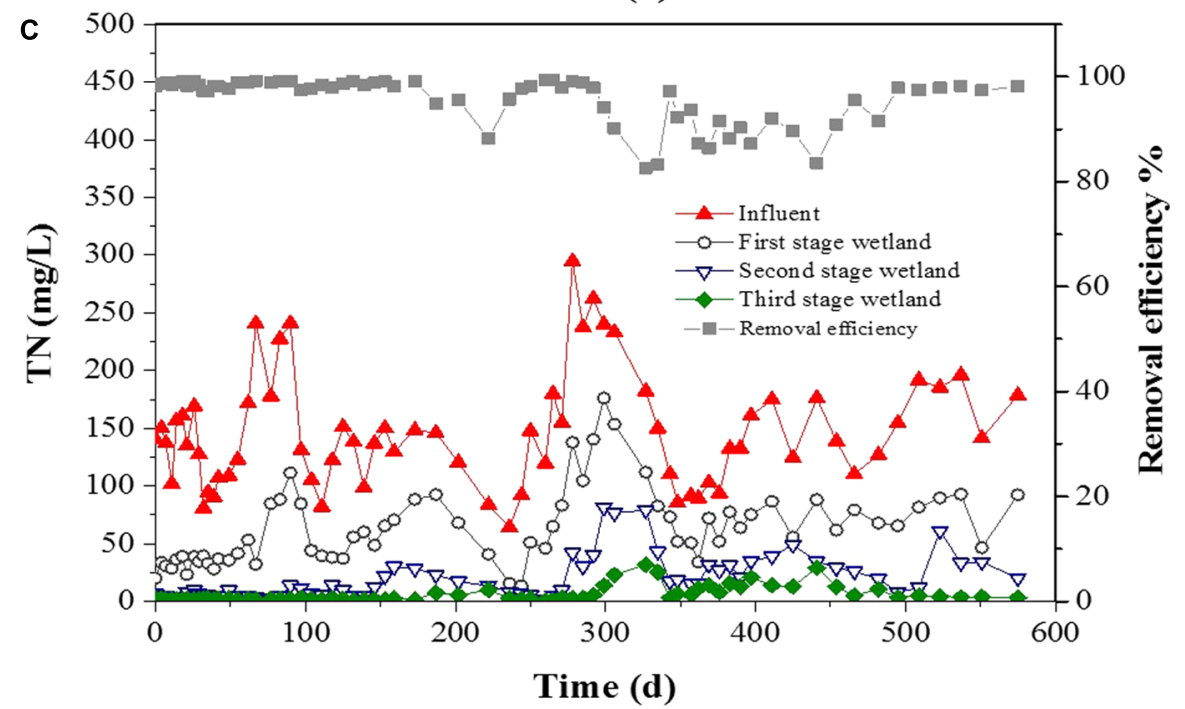

FIGURE 1 | Treatment performances in the three-stage CW. (A) COD; (B) ammonium; and (C) TN. 

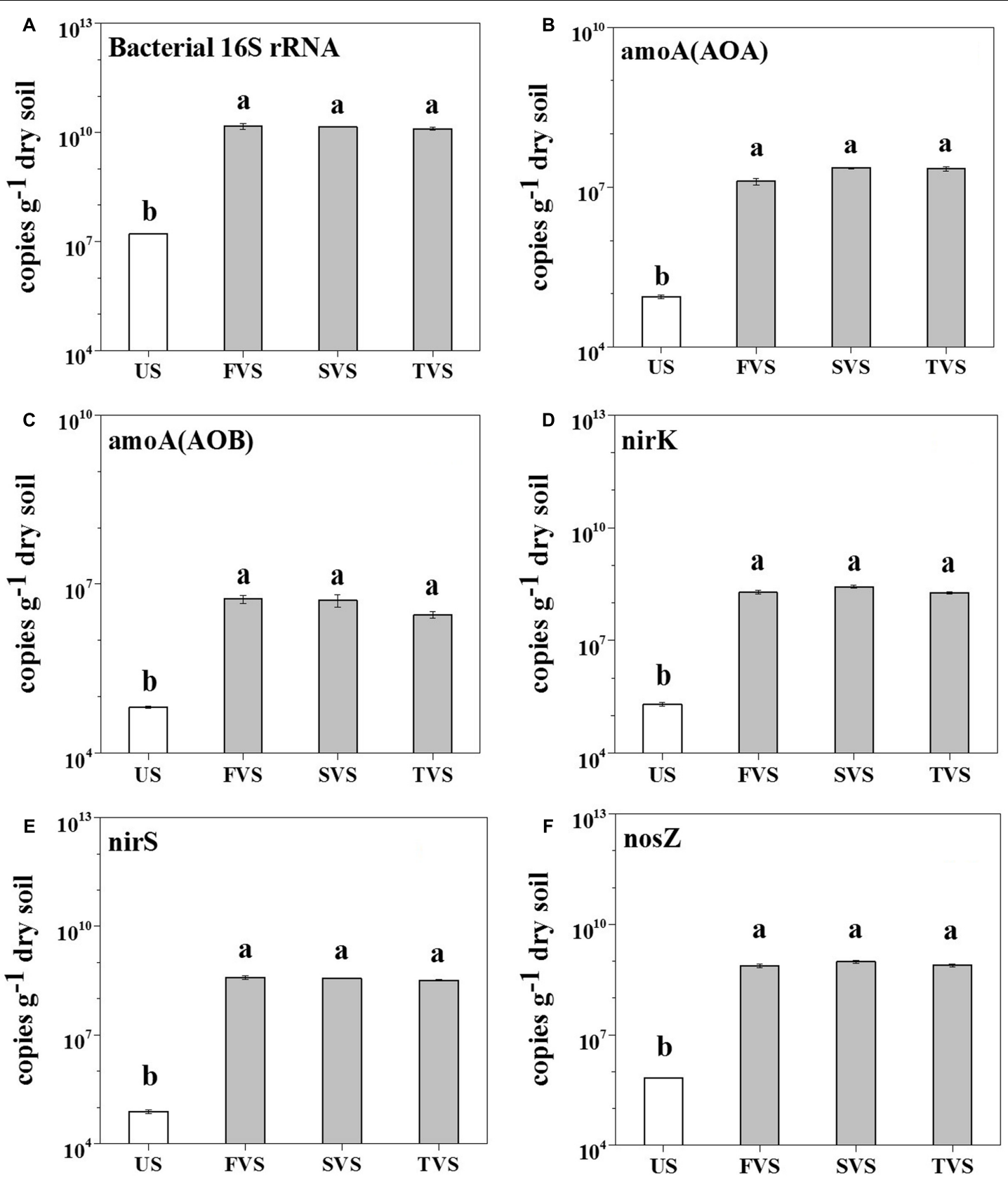

FIGURE 2 | Abundances of the bacterial 16S rRNA (A), archaeal amoA (B) and bacterial amoA (C), nirK (D), nirS (E), and nosZ (F) genes. US, sediment without M. aquaticum; FVS, sediment with $M$. aquaticum in the first-stage wetland; SVS, sediment with $M$. aquaticum in the second-stage wetland; and TVS, sediment with M. aquaticum in the third-stage wetland.

The constructed pMENs were visualized using Cytoscape 3.30 software.

\section{RESULTS}

\section{Treatment Performance}

During the operation (600 days; Figure 1), the three-stage CW achieved COD removal efficiency of $88.2 \%$ under an average inflow concentration of $484 \mathrm{mg} \mathrm{L}^{-1}$. More than $75 \%$ of removal occurred in the first-stage wetland, which had the highest removal efficiency of $66.5 \%$. The average inflow $\mathrm{NH}_{4}^{+}-\mathrm{N}$ concentration was $107 \mathrm{mg} \mathrm{L}^{-1}$, accounting for more than $70 \%$ of the $\mathrm{N}$ inputs to the wetland. The average $\mathrm{NH}_{4}^{+}-\mathrm{N}$ removal efficiency was $98.3 \%$. The average $\mathrm{TN}$ concentration of $150 \mathrm{mg} \mathrm{L}^{-1}$ in the wastewater inflow was reduced to an average effluent level of $5.9 \mathrm{mg} \mathrm{L}^{-1}$, which achieved removal efficiency of $95.8 \%$. The highest removal efficiencies of $\mathrm{NH}_{4}^{+}-\mathrm{N}$ and $\mathrm{TN}$ 
(78.6 and 71.6\%, respectively) were achieved in the secondstage CW. These performances were stable during the operation periods, even with the high average $\mathrm{COD}, \mathrm{NH}_{4}^{+}-\mathrm{N}$, and $\mathrm{TN}$ removal efficiencies of 92.3, 99.5, and 97.9\%, respectively, in winter.

\section{Change of Abundances of 16S rRNA and Functional Marker Genes by M. aquaticum}

The V4 region of the rrs gene, which encodes for the $16 \mathrm{~S}$ rRNA, archaeal and bacterial amoA, and nirK/nirS/nosZ genes, was quantified by qPCR to demonstrate the abundances of total bacteria, ammonia-oxidizing archaea (AOA), ammoniaoxidizing bacteria (AOB), and denitrifiers. In the sediment, the results showed that the abundance of the bacterial $16 \mathrm{~S}$ rRNA gene was increased significantly from $1.61 \times 10^{7}$ to $1.44 \times 10^{10}$ copies per gram dry soil (862-fold) by $M$. aquaticum (Figure 2). The abundance of archaeal $a m o A$ gene increased significantly from $8.85 \times 10^{4}$ to $1.93 \times 10^{7}$ copies per gram dry soil (218-fold), and the abundance of the bacterial amo $A$ gene increased from $6.65 \times 10^{4}$ to $5.75 \times 10^{6}$ copies per gram dry soil (86-fold). The archaeal amoA gene abundance was more increased than the bacterial $a m o A$ abundance, and it outcompeted the bacterial amo $A$ gene in all sediments containing M. aquaticum. However, there were no significant differences between the abundances of archaeal and bacterial $a m o A$ genes in the unvegetated sediment. For denitrifying genes, $M$. aquaticum significantly increased the abundance of nirK gene from $2.03 \times 10^{5}$ to $2.16 \times 10^{8}$ copies per gram dry soil (1,063-fold), while the abundance of nirS gene increased significantly from $7.73 \times 10^{4}$ to $3.58 \times 10^{8}$ copies per gram dry soil (4,620-fold). In the unvegetated sediment, the nirK outcompeted nirS gene. However, a greater abundance of the nirS gene, compared with that of the nirK gene, was detected in sediments containing $M$. aquaticum. M. aquaticum significantly increased the abundance of nos $Z$ gene from $6.84 \times 10^{5}$ to $8.31 \times 10^{8}$ copies per gram dry soil $(1,210$-fold), while in the water (Supplementary Figure 2), M. aquaticum significantly decreased the abundance of the bacterial 16S rRNA gene from $1.66 \times 10^{12}$ to $3.79 \times 10^{10}$ copies per liter water $(44$-fold), and the bacterial amoA decreased by one order of magnitude. The abundances of archaeal $a m o A$ and denitrifying genes in the water showed no significant response to M. aquaticum ( $p>0.05)$.

\section{Shift of the Microbial Community Composition by M. aquaticum}

MiSeq high-throughput sequencing of the bacterial 16S rRNA gene was performed to explore the effect of $M$. aquaticum on the structure of functional communities. In the unvegetated zone, $\alpha$-diversity indices (Supplementary Table 3 ) did not differ between sediments and water $(p>0.05)$. The sediments containing M. aquaticum showed significantly higher bacterial species richness compared with the unvegetated sediment. The composition of bacterial communities in the sediment with $M$. aquaticum differed significantly from those in the unvegetated sediment based on a principle coordinates analysis (Supplementary Figure 3).
The relative bacterial community abundances were analyzed at the phylum level (Supplementary Figure 4). Firmicutes was the most abundant phylum in the unvegetated sediment and water, accounting for 43.1 and 50.6\%, respectively, of the total effective bacterial sequences. In the sediment and water containing $M$. aquaticum, Proteobacteria was significantly enriched $(p<0.001)$, and it was the most abundant phylum, accounting for 23.73 and $46.65 \%$, respectively, of the total effective bacterial sequences. This result is similar to the previous findings of bacterial communities in constructed and natural wetlands, in which Proteobacteria was also the most dominant community (Wu et al., 2016). Within the Proteobacteria, Alpha-, Beta-, and GammaProteobacteria were all enriched substantially in sediment and water containing M. aquaticum (Supplementary Figure 5). The other dominant phyla in the sediment containing M. aquaticum were Firmicutes (13.1\%), Acidobacteria (11.9\%), Planctomycetes (11.0\%), Chloroflexi (11.5\%), Actinobacteria (9.1\%), Euryarchaeota (3.1\%), Bacteroidetes (1.9\%), and Nitrospirae (0.6\%).

To further validate the functional populations involved in $\mathrm{N}$ removal that are associated with $M$. aquaticum, a heat map of major genera was generated, as illustrated in Figure 3. For nitrifiers, the AOB Nitrosospira was enriched significantly by $M$. aquaticum in the sediment $(p<0.001)$. Two AOB Nitrosomonas and Nitrosococcus were also enriched. AOB in the vegetated sediment was dominated by Nitrosospira. The abundance of the AOA Nitrososphaera was significantly higher in the M. aquaticum-containing sediments $(p<0.001)$. Nitrososphaera was dominant among ammonia oxidizers. Two NOB Nitrospira and Nitrobacter were not detected in unvegetated sediment, but were significantly increased in the vegetated sediment $(p<0.001)$. Moreover, M. aquaticum significantly increased the abundances of the anammox bacteria Candidatus Brocadia and Candidatus Kuenenia $(p<0.001)$, while these genus were not detected in the unvegetated sediment. For the denitrifying groups, abundant denitrifiers, such as Bradyrhizobium, Rhodoplanes, Bacillus, Zoogloea, Rhizobium, Acidovorax, and Hyphomicrobium, were enriched significantly in the vegetated sediment $(p<0.001)$. Bradyrhizobium and Rhodoplanes were dominant among the denitrifiers. In the water containing $M$. aquaticum, among nitrifiers, the abundances of Nitrosococcus and Nitrosospira increased, whereas the abundances of Nitrosomonas and Nitrososphaera decreased. In addition, sequences were not obtained for NOB and anammox bacteria in the water with and without M. aquaticum. For the denitrifying group, a few denitrifiers such as Rhizobium, Rhodoplanes, and Rhodobacter were enriched significantly by M. aquaticum $(p<0.001)$.

\section{Change of the Sediment Physicochemical Properties and Microbial Communities Caused by M. aquaticum}

Compared with the unvegetated sediments, $\mathrm{NH}_{4}^{+}-\mathrm{N}, \mathrm{pH}$, and total organic carbon (TOC) decreased significantly 


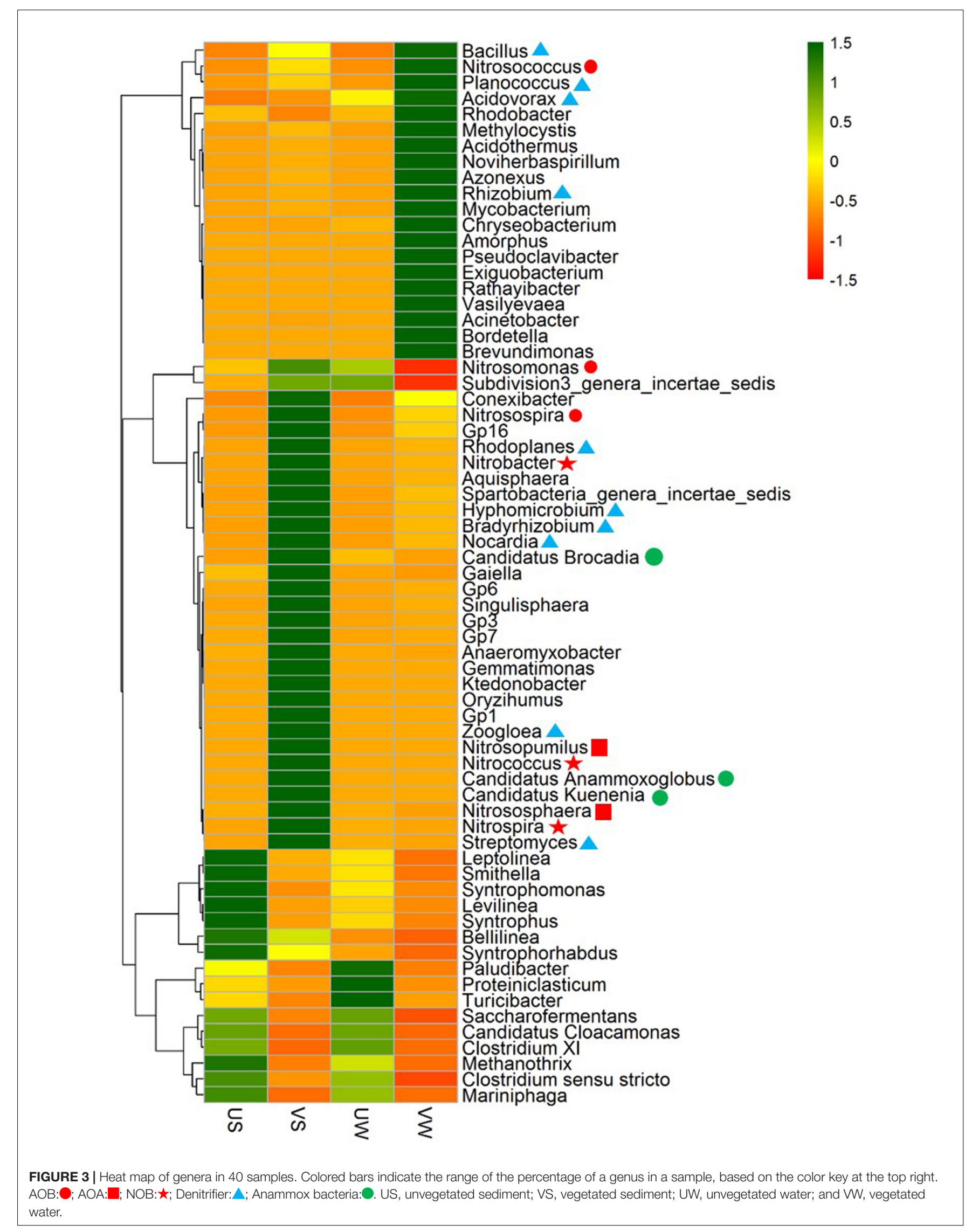


TABLE 1 | Chemical characteristics in the unvegetated and vegetated sediments.

\begin{tabular}{|c|c|c|c|c|c|c|}
\hline Sediment & $\mathrm{pH}$ & $\mathrm{NH}_{4}^{+}-\mathrm{N}(\mathrm{g} / \mathrm{kg})$ & $\mathrm{NO}_{2}^{-}-\mathrm{N}(\mathrm{mg} / \mathrm{kg})$ & $\mathrm{NO}_{3}^{-}-\mathrm{N}(\mathrm{mg} / \mathrm{kg})$ & TOC (g/kg) & $\mathrm{C} / \mathrm{N}$ \\
\hline Unvegetated & $7.18 \pm 0.08$ & $0.86 \pm 0.07$ & $0.86 \pm 0.32$ & $15.35 \pm 3.13$ & $16.01 \pm 0.18$ & $8.72 \pm 0.04$ \\
\hline Vegetated & $6.16 \pm 0.29$ & $0.13 \pm 0.06$ & $1.66 \pm 0.35$ & $6.45 \pm 1.50$ & $9.34 \pm 0.28$ & $10.03 \pm 0.24$ \\
\hline
\end{tabular}

$(p<0.001)$, whereas $\mathrm{NO}_{2}^{-}-\mathrm{N}$ increased, in the sediments containing $M$. aquaticum (Table 1). CCA was used to examine the relationship between the environmental variables and the microbial community composition. The results of the CCA, a significant model at the confidence level of $p \leq 0.001$, indicated that sediment $\mathrm{NH}_{4}^{+}-\mathrm{N}$ and TOC were important environmental factors controlling the microbial community structure (Figure 4). The importance of these environmental attributes was verified by Mantel tests based on their significant correlation $(p \leq 0.001)$ as well (Table 2).

\section{Change of Microbial Interactions by M. aquaticum}

Interactions among different microbial species in the CWs were calculated using a relative abundance matrix of genuslevel OTUs with 97\% similarity, and they were constructed in a network to describe the effect of $M$. aquaticum on the microbial interactions (Figure $\mathbf{5}$ and Supplementary Figure 6). The structure of the identified networks with and without $M$. aquaticum differed substantially in terms of their network composition, interaction patterns (positive, zero, or negative), and node overlap, which demonstrated that $M$. aquaticum greatly altered the interactions among different microbial species. A small and simple connected module of nodes corresponded to $\mathrm{N}$-cycling members in the unvegetated sediments, primarily including ammonia-oxidizing Nitrososphaera and denitrifiers such as Acinetobacter and Thauera, and these species did not show any interaction. However, in the sediment containing $M$. aquaticum, a large and densely connected module of nodes corresponded to members involved in $\mathrm{N}$ removal, primarily including ammoniaoxidizing Nitrososphaera, nitrite-oxidizing Nitrospira, anaerobic ammonia-oxidizing Candidatus Kuenenia and denitrifiers such as Rhodoplanes, Bradyrhizobium, and Hyphomicrobium. These groups were distributed widely in the vegetated sediments, and they showed positive ecological associations with different species. The positive interactions between the AOA Nitrososphaera and denitrifiers were stimulated by M. aquaticum. Nitrososphaera showed positive interactions with the anaerobic denitrifier Rhodoplanes. Heterotrophic denitrifiers, such as Rhodoplanes, Bradyrhizobium, and Hyphomicrobium, were enriched and distributed widely in the sediments containing $M$. aquaticum. Moreover, microorganisms carry out fermentation including Clostridium and Smithella were also enriched in these sediments (Ezeji et al., 2007; Wawrik et al., 2016). The enriched denitrifiers showed positive relationships with fermentative bacteria. For example, Rhodoplanes was frequently found to have positive interactions with the
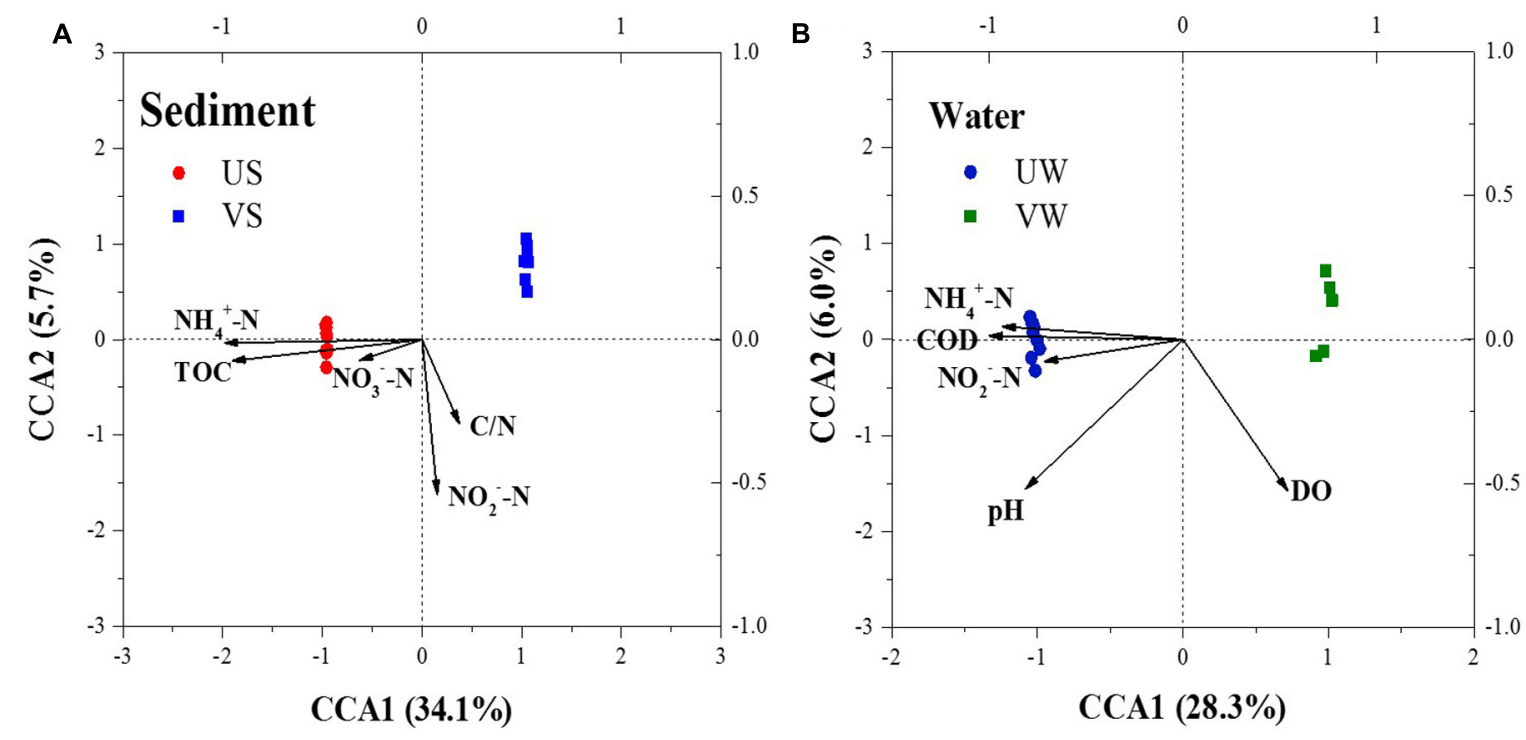

FIGURE 4 | Canonical correspondence analysis (CCA) ordination plots for the first two dimensions showing the relationship between the bacterial communities (symbols) and environmental factors (arrows). (A) sediment; (B) water. US, unvegetated sediment; VS, vegetated sediment; UW, unvegetated water; and WW, vegetated water. 
anaerobic fermentative bacteria Clostridium. Moreover, positive relationships among the denitrifiers were observed. However, in the vegetated water (Supplementary Figure 6), the most abundant genus, Rhizobium, displayed co-occurrence through positive correlations with some denitrifiers or potential denitrifiers, including Rhodoplanes, Bradyrhizobium, and Rhodobacter.

\section{DISCUSSION}

In China, discharges of COD and ammonia from livestock farms accounted for 41.9 and $41.5 \%$, respectively, of total emission loads (Zhou et al., 2013). Our CW planted with M. aquaticum was used successfully for swine wastewater treatment, and it exhibited promising performance. The COD removal efficiency of $88.2 \%$ was higher than those of free water surface CWs (FWS CWs), which are commonly used to treat domestic wastewater and generally exhibit typical removal efficiencies of $70 \%$ (Zhang et al., 2014). The $\mathrm{NH}_{4}^{+}-\mathrm{N}$ removal efficiency of $98.3 \%$ was higher than the reported treatment efficiencies of $40-50 \%$ in FWS CWs (Vymazal, 2007). The TN removal efficiency in our CW was $95.8 \%$, which was higher than the TN removal efficiencies reported by other studies, such as $25 \%$ in a CW planted with Phragmites communis and Scirpus validus (Ibekwe et al., 2003), and 39.6\% for 268 subsurface horizontal flow CWs in Europe (Ye and Li, 2009).

In our $\mathrm{CW}$, which achieved high and stable $\mathrm{N}$ treatment performance during long-term operation, we used molecular biology tools to explore the mechanisms underlying its good performance. Our results revealed a remarkable enrichment of functional groups involved in $\mathrm{N}$ removal in sediment compared with those in the water, indicating that sediment may be of greater importance than the water as a site for $\mathrm{N}$ removal in the CW planted with M. aquaticum. M. aquaticum may affect microbial community by decreasing physicochemical factors such as $\mathrm{NH}_{4}^{+}-\mathrm{N}$ and TOC. These modifications, in turn, may change the abundances and structure of nitrifying and denitrifying communities in sediment (Vila-Costa et al., 2016). In many previous studies, the $\mathrm{NH}_{4}^{+}-\mathrm{N}$ concentration was always proven to be a prime factor in the $\mathrm{N}$ cycle in CWs (Sims et al., 2013). In the present study, the AOB Nitrosospira and AOA Nitrososphaera were significantly enriched in the vegetated sediments $(p<0.001)$, and $\mathrm{NH}_{4}^{+}-\mathrm{N}$ was significantly lower in the vegetated sediments than those of the unvegetated sediments $(p<0.001)$. As previously reported, the AOB Nitrosospira and AOA exhibit a higher ammonia affinity and adaptability to low ammonia concentrations (Schramm et al., 1998; Herrmann et al., 2009). Thus, the low concentrations of $\mathrm{NH}_{4}^{+}-\mathrm{N}$ in the vegetated sediments may favor the growth of the AOB Nitrosospira and the AOA Nitrososphaera. TOC has been considered as a favorable factor in shaping the soil microbial community composition (Shen et al., 2015). The transformation of TOC can supply labile nutrients and energy which could stimulate the growth of denitrifiers (Aldén et al., 2001).
Nitrifiers, including $\mathrm{AOA}, \mathrm{AOB}$, and $\mathrm{NOB}$, were enriched significantly in the sediment containing $M$. aquaticum. The enrichment of nitrifiers may be due to the oxidized zone created by oxygen released from the roots of Myriophyllum spp. (Laskov et al., 2006). The qPCR results indicated M. aquaticum significantly increased the abundances of the archaeal and bacterial amoA genes. Previous studies demonstrated plantspecific effects on the abundances of archaeal and bacterial amoA genes. Archaeal amoA abundances, but not bacterial amoA abundances, were significantly higher in sediments containing L. uniflora, Lolium perenne, and Festuca rubra. While Ceratophyllum demersum and Vallisneria spinulosa increased bacterial amoA abundances, but not archaeal amoA, compared with unvegetated sediments (Herrmann et al., 2008; Zhao et al., 2014; Thion et al., 2016). In the present study, $M$. aquaticum significantly increased both archaeal and bacterial amoA abundances, suggesting that it maybe advantageous for both $\mathrm{AOA}$ and $\mathrm{AOB}$. Despite our observing significant increases in both $\mathrm{AOA}$ and $\mathrm{AOB}$, the $\mathrm{AOA}$ dominated numerically in all sediments containing $M$. aquaticum. This trend suggests that AOA might be better adapted to the microaerophilic conditions in the sediment, or they may benefit from the organic compounds released by roots for mixotrophic growth (Leininger et al., 2006). Other factors known to affect $\mathrm{AOA}$ and $\mathrm{AOB}$ are $\mathrm{pH}$ and the ammonia concentration. The greater enrichment of AOA, compared with that of $\mathrm{AOB}$, may result from the significant decrease of the $\mathrm{pH}$ and the ammonium in the sediment containing $M$. aquaticum, as AOA are generally predominant in acidic soils and at low ammonia concentrations (Herrmann et al., 2009). The high-throughput sequencing results further indicate that the AOA that are most enriched by $M$. aquaticum was Nitrososphaera, and Nitrososphaera dominated among ammonia oxidizers. This type of archaea is found frequently in soil and the rhizosphere layer because it exhibits both facultative aerobic and anaerobic characteristics (Bouali et al., 2012). Moreover, organic carbon compounds, such as pyruvate, a constituent of plant root exudates, is essential for the high growth yields of Nitrososphaera and could contribute to the high proportion of Nitrososphaera (Tourna et al., 2011). Additionally, the enriched anammox bacteria may be due to the oxic (photosynthesis)-anoxic (submerged) interface provided by $M$. aquaticum where anammox mainly occurs (Zhu et al., 2015). Therefore, the more probable pathway for $\mathrm{NH}_{4}^{+}-\mathrm{N}$ removal was through a combination of nitrifying and anammox bacteria, which enhanced the ammonium removal.

The abundance of denitrifying genes nirK, nirS, and nos $Z$ was significantly higher in the sediment containing M. aquaticum. Thus, vegetation is an important factor controlling the denitrifier community size in the CW. Previous studies also demonstrated plant-specific effects on the abundances of the nirK and nirS genes. Of the two well-studied macrophytes, Phragmites australis yielded significant increases in nirK and nos $Z$ abundances, but not nirS abundances, while Typha did not have any obvious effect on these genes in a FWS CW (García-Lledó et al., 2011). In our study, the abundance of the nirS gene 
TABLE 2 | Relationships of the microbial community structure with environmental factors as revealed by Mantel tests.

\begin{tabular}{|c|c|c|c|c|c|}
\hline \multicolumn{3}{|c|}{ Sediment } & \multicolumn{3}{|c|}{ Water } \\
\hline Environmental attribute & $R$-value & $P$-value & Environmental attribute & $R$-value & $P$-value \\
\hline $\mathrm{pH}$ & 0.958 & 0.001 & $\mathrm{pH}$ & 0.601 & 0.001 \\
\hline $\mathrm{NH}_{4}^{+}-\mathrm{N}(\mathrm{g} / \mathrm{kg})$ & 0.955 & 0.001 & $\mathrm{NH}_{4}^{+}-\mathrm{N}(\mathrm{mg} / \mathrm{L})$ & 0.876 & 0.001 \\
\hline $\mathrm{NO}_{2}^{-}-\mathrm{N}(\mathrm{mg} / \mathrm{kg})$ & 0.120 & 0.075 & $\mathrm{NO}_{2}^{-}-\mathrm{N}(\mathrm{mg} / \mathrm{L})$ & 0.225 & 0.014 \\
\hline $\mathrm{NO}_{3}^{-}-\mathrm{N}(\mathrm{mg} / \mathrm{kg})$ & 0.046 & 0.179 & $\mathrm{NO}_{3}^{-}-\mathrm{N}(\mathrm{mg} / \mathrm{L})$ & 0.783 & 0.001 \\
\hline TOC $(g / k g)$ & 0.891 & 0.001 & COD (mg/L) & 0.767 & 0.001 \\
\hline $\mathrm{C} / \mathrm{N}$ & 0.098 & 0.046 & $\mathrm{DO}(\mathrm{mg} / \mathrm{L})$ & 0.263 & 0.007 \\
\hline
\end{tabular}

Significant differences $(p \leq 0.001)$ are indicated in bold. DO, dissolved oxygen.

was greater increased than that of the nirK gene, and the nirS gene outnumbered nirK gene in the sediments. These results indicate that there was stronger plant species effect on the nirS communities than on the nirK communities. The nos $Z$ abundance did not differ significantly from the nirK/nirS abundance. As our study focus on the effect of the macrophytes on the microbial communities responsible for $\mathrm{N}$ removal, thus, we adopted the commonly used primers in many previous studies detecting the nos $Z$ gene, and did not target representatives from clade II, which might have underestimated the actual nos $Z$ gene abundance in CWs. This contrasts with previous studies demonstrating that the nos $Z$ abundance is frequently lower than that of nir genes in the environment, as many bacterial isolates that harbor either nirS or nirK genes lack the nosZ gene (Henry et al., 2006; Hallin et al., 2009). The high abundance of the nos $Z$ gene in our study during long-term operation of the CW may enhance the last step in the denitrification pathway, leading to a potential reduction in the emission of the greenhouse gas $\mathrm{N}_{2} \mathrm{O}$ (Zhi et al., 2015). The high-throughput sequencing results showed that abundant denitrifiers and potential denitrifiers were enriched significantly by $M$. aquaticum. The enriched Acidovorax, Bacillus, Bradyrhizobium, Hyphomicrobium, Rhizobium, and Rhodoplanes play important roles in wastewater treatment (Guo et al., 2013). These most increased denitrifiers belong to the Alpha-Proteobacteria. Within the phylum Proteobacteria, nearly half of all microorganisms have a complete denitrification pathway including nir, nor, and nos $Z$ genes (Graf et al., 2014), which may explain the high abundances of both the nir and nos $Z$ genes in our study. Previously, the effects of different macrophytes on the structure of the denitrifying community in the rhizosphere have been reported in freshwater wetlands (Angeloni et al., 2006; Ruiz-Rueda et al., 2009). The effect on the compositions of the denitrifying populations could be due to differences in root exudates, which have been shown to influence the abundances and diversity of microorganisms (Orwin et al., 2006). Lu et al. (2014) found that the fatty acid methyl esters and fatty acid amides from the root exudates of aquatic duckweed stimulated removal of denitrifying bacteria. Nevertheless, Henry et al. (2008) did not find strong effect on the structure and density of the denitrifying communities when using different artificial root exudates.
To elucidate the effect of $M$. aquaticum on the microbial interactions among various populations, we used RMT-based network approaches to examine the interactions of the microbial communities in response to this species. Previously, correlation networks have been successfully applied to identify bacterial interactions in marine, soil, and activated sludge samples (Ruan et al., 2006; Zhou et al., 2010; Ju et al., 2014). Our results indicated that $M$. aquaticum dramatically shifted the interactions of microbial populations. Particularly, it greatly enhanced positive ecological associations. A positive relationship is most likely due to mutualism or commensalism (Faust and Raes, 2012). The AOA Nitrososphaera showed a positive interaction with the denitrifier Rhodoplanes, suggesting that $M$. aquaticum may provide an oxygenated zone for nitrifiers growing in the sediment and enhance nitrification via oxygen release from roots, with nitrite and nitrate formed serving as substrates for denitrifiers in the adjacent anaerobic zone (Reddy et al., 1989; Ruiz-Rueda et al., 2009). The stimulated positive interactions between fermentative bacteria and the denitrifying bacteria Rhodoplanes suggested that the major products of anaerobic fermentation (acetate, propionate, and butyrate) may be used as carbon sources by Rhodoplanes (Paul et al., 1989). The enriched fermentative and denitrifying bacteria suggest that there are more available carbon sources in the vegetated sediment, which may be related to the organic carbon provided by $M$. aquaticum. The positive associations among denitrifiers such as Rhodoplanes and Streptomyces demonstrate that closely functional species have a related ecologically preference, which may promote the $\mathrm{N}$ removal via denitrification (Peng et al., 2014).

In this study, the effect of macrophytes on nitrifying and denitrifying bacterial communities was characterized in a pilot-scale, surface flow CW to treat high-strength swine wastewater. The $\mathrm{CW}$ planted with $M$. aquaticum exhibited extraordinary performance for long-term $\mathrm{N}$ removal without the need for costly aeration. 16S rRNA, nitrifying and denitrifying genes were enriched significantly in the sediment containing $M$. aquaticum. M. aquaticum markedly changed the structure of the microbial community, and the nitrifiers, anammox bacteria, and denitrifiers were significantly enriched in the sediment. A CCA and Mantle tests indicated that $M$. aquaticum may shift the sediment microbial community by changing the sediment chemical 


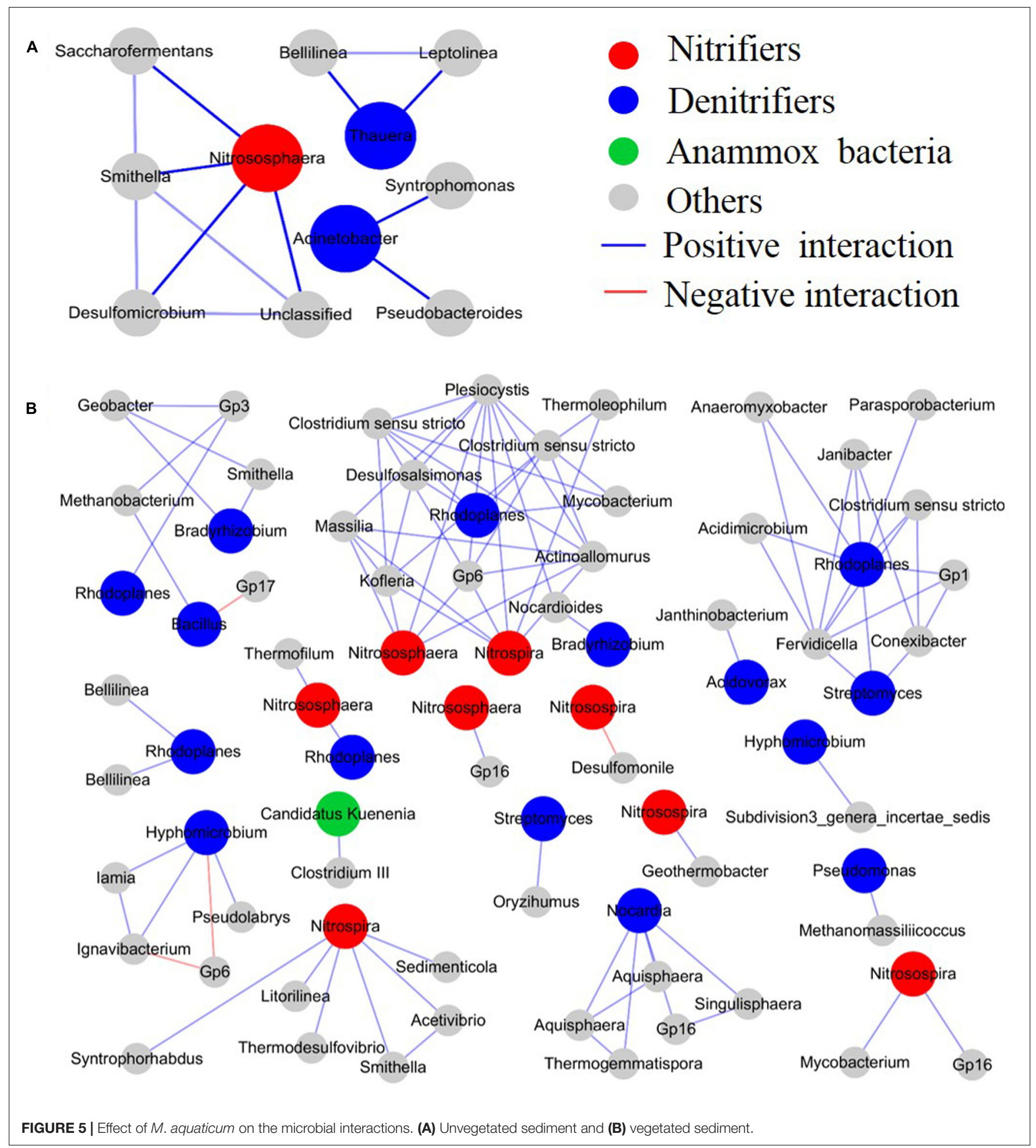

properties, as the $\mathrm{NH}_{4}^{+}-\mathrm{N}$ and TOC concentrations were significantly lower than those of the unvegetated sediment. Positive relationships among nitrifiers, denitrifiers, and other bacteria were stimulated by $M$. aquaticum in the sediment.

\section{AUTHOR CONTRIBUTIONS}

HS performed the experiment, analyzed the data, and wrote the paper. FL designed the experiment, performed the experiment, and revised the paper. SX analyzed the data 
and revised the paper. SW analyzed the data and revised the paper. GZ revised the paper. YD analyzed the data and revised the paper. JW conceived and designed the experiment and gave comments on the paper. XZ instructed the experiment and revised the paper.

\section{FUNDING}

This research was supported by the National Natural Science Foundation of China (Grant Nos. 41371266 and 31670507), the Interdisciplinary Innovation Team Program of the Chinese Academy of Sciences (Grant Nos. 2015, the Team for the Directional Biotransformation of Environmental Pollutants), and the Major Science and Technology Program for Water Pollution Control and Treatment

\section{REFERENCES}

Aldén, L., Demoling, F., and Bååth, E. (2001). Rapid method of determining factors limiting bacterial growth in soil. Appl. Environ. Microbiol. 67, 1830-1838. doi: 10.1128/AEM.67.4.1830-1838.2001

Angeloni, N. L., Jankowski, K. J., Tuchman, N. C., and Kelly, J. J. (2006). Effects of an invasive cattail species (Typha $\times$ glauca) on sediment nitrogen and microbial community composition in a freshwater wetland. FEMS Microbiol. Lett. 263, 86-92. doi: 10.1111/j.1574-6968.2006.00409.x

Beman, J. M., Arrigo, K. R., and Matson, P. A. (2005). Agricultural runoff fuels large phytoplankton blooms in vulnerable areas of the ocean. Nature 434, 211-214. doi: $10.1038 /$ nature 03370

Bodelier, P., Libochant, J. A., Blom, C., and Laanbroek, H. J. (1996). Dynamics of nitrification and denitrification in root-oxygenated sediments and adaptation of ammonia-oxidizing bacteria to low-oxygen or anoxic habitats. Appl. Environ. Microbiol. 62, 4100-4107.

Bouali, M., Zrafi-Nouira, I., Bakhrouf, A., Le Paslier, D., Chaussonnerie, S., Ammar, E., et al. (2012). The structure and spatio-temporal distribution of the Archaea in a horizontal subsurface flow constructed wetland. Sci. Total Environ. 435, 465-471. doi: 10.1016/j.scitotenv.2012.07.047

Caporaso, J. G., Lauber, C. L., Walters, W. A., Berg-Lyons, D., Huntley, J., Fierer, N., et al. (2012). Ultra-high-throughput microbial community analysis on the Illumina HiSeq and MiSeq platforms. ISME J. 6, 1621-1624. doi: 10.1038/ismej. 2012.8

Cronk, J. K. (1996). Constructed wetlands to treat wastewater from dairy and swine operations: a review. Agric. Ecosyst. Environ. 58, 97-114. doi: 10.1016/01678809(96)01024-9

Deng, Y., Jiang, Y.-H., Yang, Y., He, Z., Luo, F., and Zhou, J. (2012). Molecular ecological network analyses. BMC Bioinformat. 13:113. doi: 10.1186/14712105-13-113

Dong, X., and Reddy, G. B. (2010). Soil bacterial communities in constructed wetlands treated with swine wastewater using PCR-DGGE technique. Bioresour. Technol. 101, 1175-1182. doi: 10.1016/j.biortech.2009.09.071

Edgar, R. C. (2013). UPARSE: highly accurate OTU sequences from microbial amplicon reads. Nat. Methods 10, 996-998. doi: 10.1038/nmeth.2604

Ezeji, T., Qureshi, N., and Blaschek, H. P. (2007). Butanol production from agricultural residues: impact of degradation products on Clostridium beijerinckii growth and butanol fermentation. Biotechnol. Bioeng. 97, 1460-1469. doi: 10.1002/bit.21373

Faust, K., and Raes, J. (2012). Microbial interactions: from networks to models. Nat. Rev. Microbiol. 10, 538-550. doi: 10.1038/nrmicro2832

Federation, W. E., and Association, A. P. H. (2005). Standard Methods for the Examination of Water and Wastewater. Washington, DC: American Public Health Association.

García-Lledó, A., Vilar-Sanz, A., Trias, R., Hallin, S., and Bañeras, L. (2011). Genetic potential for $\mathrm{N} 2 \mathrm{O}$ emissions from the sediment of a free water surface of China (Grant Nos. 2015ZX07206-006 and 2014ZX072 04-005).

\section{ACKNOWLEDGMENT}

We thank Scott Lloyd, Ph.D., from Liwen Bianji, Edanz Group China (www.liwenbianji.cn/ac), for editing the English text of this manuscript.

\section{SUPPLEMENTARY MATERIAL}

The Supplementary Material for this article can be found online at: https://www.frontiersin.org/articles/10.3389/fmicb. 2017.01932/full\#supplementary-material

constructed wetland. Water Res. 45, 5621-5632. doi: 10.1016/j.watres.2011. 08.025

Graf, D. R., Jones, C. M., and Hallin, S. (2014). Intergenomic comparisons highlight modularity of the denitrification pathway and underpin the importance of community structure for N2O emissions. PLOS ONE 9:e114118. doi: 10.1371/ journal.pone.0114118

Guo, F., Ju, F., Cai, L., and Zhang, T. (2013). Taxonomic precision of different hypervariable regions of $16 \mathrm{~S}$ rRNA gene and annotation methods for functional bacterial groups in biological wastewater treatment. PLOS ONE 8:e76185. doi: 10.1371/journal.pone.0076185

Hallin, S., Jones, C. M., Schloter, M., and Philippot, L. (2009). Relationship between N-cycling communities and ecosystem functioning in a 50-year-old fertilization experiment. ISME J. 3, 597-605. doi: 10.1038/ismej. 2008.128

He, T., Guan, W., Luan, Z., and Xie, S. (2016). Spatiotemporal variation of bacterial and archaeal communities in a pilot-scale constructed wetland for surface water treatment. Appl. Microbiol. Biotechnol. 100, 1479-1488. doi: 10.1007/s00253015-7072-5

Henry, S., Bru, D., Stres, B., Hallet, S., and Philippot, L. (2006). Quantitative detection of the nosZ gene, encoding nitrous oxide reductase, and comparison of the abundances of $16 \mathrm{~S}$ rRNA, narG, nirK, and nosZ genes in soils. Appl. Environ. Microbiol. 72, 5181-5189. doi: 10.1128/AEM. 00231-06

Henry, S., Texier, S., Hallet, S., Bru, D., Dambreville, C., Chèneby, D., et al. (2008). Disentangling the rhizosphere effect on nitrate reducers and denitrifiers: insight into the role of root exudates. Environ. Microbiol. 10, 3082-3092. doi: 10.1111/ j.1462-2920.2008.01599.x

Herrmann, M., Saunders, A. M., and Schramm, A. (2008). Archaea dominate the ammonia-oxidizing community in the rhizosphere of the freshwater macrophyte Littorella uniflora. Appl. Environ. Microbiol. 74, 3279-3283. doi: 10.1128/AEM.02802-07

Herrmann, M., Saunders, A. M., and Schramm, A. (2009). Effect of lake trophic status and rooted macrophytes on community composition and abundance of ammonia-oxidizing prokaryotes in freshwater sediments. Appl. Environ. Microbiol. 75, 3127-3136. doi: 10.1128/AEM.02806-08

Ibekwe, A. M., Grieve, C. M., and Lyon, S. R. (2003). Characterization of microbial communities and composition in constructed dairy wetland wastewater effluent. Appl. Environ. Microbiol. 69, 5060-5069. doi: 10.1128/AEM.69.9.50605069.2003

Ju, F., Xia, Y., Guo, F., Wang, Z., and Zhang, T. (2014). Taxonomic relatedness shapes bacterial assembly in activated sludge of globally distributed wastewater treatment plants. Environ. Microbiol. 16, 2421-2432. doi: 10.1111/1462-2920. 12355

Karjalainen, H., Stefansdottir, G., Tuominen, L., and Kairesalo, T. (2001). Do submersed plants enhance microbial activity in sediment? Aquat. Bot. 69, 1-13. doi: 10.1016/S0304-3770(00)00138-8 
Kong, Y. (2011). Btrim: a fast, lightweight adapter and quality trimming program for next-generation sequencing technologies. Genomics 98, 152-153. doi: 10.1016/j.ygeno.2011.05.009

Laskov, C., Horn, O., and Hupfer, M. (2006). Environmental factors regulating the radial oxygen loss from roots of Myriophyllum spicatum and Potamogeton crispus. Aquat. Bot. 84, 333-340. doi: 10.1016/j.aquabot.2005.12.005

Legendre, P., and Legendre, L. F. (2012). Numerical Ecology. Amsterdam: Elsevier.

Leininger, S., Urich, T., Schloter, M., Schwark, L., Qi, J., Nicol, G., et al. (2006). Archaea predominate among ammonia-oxidizing prokaryotes in soils. Nature 442, 806-809. doi: 10.1038/nature04983

Liu, F., Zhang, S., Wang, Y., Li, Y., Xiao, R., Li, H., et al. (2016). Nitrogen removal and mass balance in newly-formed Myriophyllum aquaticum mesocosm during a single 28-day incubation with swine wastewater treatment. J. Environ. Manage. 166, 596-604. doi: 10.1016/j.jenvman.2015.11.020

Lu, Y., Zhou, Y., Nakai, S., Hosomi, M., Zhang, H., Kronzucker, H. J., et al. (2014). Stimulation of nitrogen removal in the rhizosphere of aquatic duckweed by root exudate components. Planta 239, 591-603. doi: 10.1007/s00425-013$1998-6$

Magoč, T., and Salzberg, S. L. (2011). FLASH: fast length adjustment of short reads to improve genome assemblies. Bioinformatics 27, 2957-2963. doi: 10.1093/ bioinformatics/btr507

Ministry of Environmental Protection, National Bureau of Statistics of China, Ministry of Agriculture (2010). The Bulletin on the First National Census on Pollution Sources. Beijing: Ministry of Environmental Protection.

Orwin, K. H., Wardle, D. A., and Greenfield, L. G. (2006). Ecological consequences of carbon substrate identity and diversity in a laboratory study. Ecology 87, 580-593. doi: 10.1890/05-0383

Ottosen, L. D. M., Risgaard-Petersen, N., and Nielsen, L. P. (1999). Direct and indirect measurements of nitrification and denitrification in the rhizosphere of aquatic macrophytes. Aquat. Microb. Ecol. 19, 81-91. doi: 10.3354/ame 019081

Patra, A. K., Abbadie, L., Clays-Josserand, A., Degrange, V., Grayston, S. J., Guillaumaud, N., et al. (2006). Effects of management regime and plant species on the enzyme activity and genetic structure of $\mathrm{N}$-fixing, denitrifying and nitrifying bacterial communities in grassland soils. Environ. Microbiol. 8, 1005-1016. doi: 10.1111/j.1462-2920.2006.00992.x

Paul, J., Beauchamp, E., and Trevors, J. (1989). Acetate, propionate, butyrate, glucose, and sucrose as carbon sources for denitrifying bacteria in soil. Can. J. Microbiol. 35, 754-759. doi: 10.1139/m89-126

Pelissari, C., Ávila, C., Trein, C. M., García, J., de Armas, R. D., and Sezerino, P. H. (2017). Nitrogen transforming bacteria within a full-scale partially saturated vertical subsurface flow constructed wetland treating urban wastewater. Sci. Total Environ. 574, 390-399. doi: 10.1016/j.scitotenv.2016.08.207

Peng, X., Guo, F., Ju, F., and Zhang, T. (2014). Shifts in the microbial community, nitrifiers and denitrifiers in the biofilm in a full-scale rotating biological contactor. Environ. Sci. Technol. 48, 8044-8052. doi: 10.1021/es5017087

Petersen, N. R., and Jensen, K. (1997). Nitrification and denitrification in the rhizosphere of the aquatic macrophyte Lobelia dortmanna L. Limnol. Oceanogr. 42, 529-537. doi: 10.4319/lo.1997.42.3.0529

Philippot, L., Piutti, S., Martin-Laurent, F., Hallet, S., and Germon, J. C. (2002). Molecular analysis of the nitrate-reducing community from unplanted and maize-planted soils. Appl. Environ. Microbiol. 68, 6121-6128. doi: 10.1128/ AEM.68.12.6121-6128.2002

Philippot, L., Raaijmakers, J. M., Lemanceau, P., and Van Der Putten, W. H. (2013). Going back to the roots: the microbial ecology of the rhizosphere. Nat. Rev. Microbiol. 11, 789-799. doi: 10.1038/nrmicro3109

Reddy, K., Patrick, W., and Lindau, C. (1989). Nitrification-denitrification at the plant root-sediment interface in wetlands. Limnol. Oceanogr. 34, 1004-1013. doi: 10.4319/lo.1989.34.6.1004

Ruan, Q., Dutta, D., Schwalbach, M. S., Steele, J. A., Fuhrman, J. A., and Sun, F. (2006). Local similarity analysis reveals unique associations among marine bacterioplankton species and environmental factors. Bioinformatics 22, 2532-2538. doi: 10.1093/bioinformatics/btl417

Ruiz-Rueda, O., Hallin, S., and Bañeras, L. (2009). Structure and function of denitrifying and nitrifying bacterial communities in relation to the plant species in a constructed wetland. FEMS Microbiol. Ecol. 67, 308-319. doi: 10.1111/j. 1574-6941.2008.00615.x
Schramm, A., de Beer, D., Wagner, M., and Amann, R. (1998). Identification and activities in situ of nitrosospiraand Nitrospira spp. as dominant populations in a nitrifying fluidized bed reactor. Appl. Environ. Microbiol. 64, 3480-3485.

Shen, Z., Zhou, Y., Liu, J., Xiao, Y., Cao, R., and Wu, F. (2015). Enhanced removal of nitrate using starch/PCL blends as solid carbon source in a constructed wetland. Bioresour. Technol. 175, 239-244. doi: 10.1016/j.biortech.2014. 10.006

Sims, A., Zhang, Y., Gajaraj, S., Brown, P. B., and Hu, Z. (2013). Toward the development of microbial indicators for wetland assessment. Water Res. 47, 1711-1725. doi: 10.1016/j.watres.2013.01.023

Stottmeister, U., Wießner, A., Kuschk, P., Kappelmeyer, U., Kästner, M., Bederski, O., et al. (2003). Effects of plants and microorganisms in constructed wetlands for wastewater treatment. Biotechnol. Adv. 22, 93-117. doi: 10.1016/j. biotechadv.2003.08.010

Thion, C. E., Poirel, J. D., Cornulier, T., De Vries, F. T., Bardgett, R. D., and Prosser, J. I. (2016). Plant nitrogen-use strategy as a driver of rhizosphere archaeal and bacterial ammonia oxidiser abundance. FEMS Microbiol. Ecol. 92:fiw091. doi: 10.1093/femsec/fiw091

Tourna, M., Stieglmeier, M., Spang, A., Könneke, M., Schintlmeister, A., Urich, T., et al. (2011). Nitrososphaera viennensis, an ammonia oxidizing archaeon from soil. Proc. Natl. Acad. Sci. U.S.A. 108, 8420-8425. doi: 10.1073/pnas.1013 488108

Vartapetian, B. B., and Jackson, M. B. (1997). Plant adaptations to anaerobic stress. Ann. Bot. 79(Suppl. 1), 3-20. doi: 10.1093/oxfordjournals.aob.a010303

Vila-Costa, M., Pulido, C., Chappuis, E., Calviño, A., Casamayor, E. O., and Gacia, E. (2016). Macrophyte landscape modulates lake ecosystem-level nitrogen losses through tightly coupled plant-microbe interactions. Limnol. Oceanogr. 61, 78-88. doi: 10.1002/lno.10209

Vymazal, J. (2007). Removal of nutrients in various types of constructed wetlands. Sci. Total Environ. 380, 48-65. doi: 10.1016/j.scitotenv.2006.09.014

Vymazal, J. (2011). Constructed Wetlands for wastewater treatment: five decades of experiencet. Environ. Sci. Technol. 45, 61-69. doi: 10.1021/es1 $01403 \mathrm{q}$

Wang, Q., Garrity, G. M., Tiedje, J. M., and Cole, J. R. (2007). Naive Bayesian classifier for rapid assignment of rRNA sequences into the new bacterial taxonomy. Appl. Environ. Microbiol. 73, 5261-5267. doi: 10.1128/AEM. 00062-07

Wawrik, B., Marks, C. R., Davidova, I. A., McInerney, M. J., Pruitt, S., Duncan, K. E., et al. (2016). Methanogenic paraffin degradation proceeds via alkane addition to fumarate by 'Smithella'spp. mediated by a syntrophic coupling with hydrogenotrophic methanogens. Environ. Microbiol. 18, 2604-2619. doi: 10.1111/1462-2920.13374

Wu, Y., Rui, H., Yang, X., Fang, X., Xi, C., Di, Y., et al. (2016). Correlating microbial community with physicochemical indices and structures of a fullscale integrated constructed wetland system. Appl. Microbiol. Biotechnol. 100, 6917-6926. doi: 10.1007/s00253-016-7526-4

Yang, Y., Gao, Y., Wang, S., Xu, D., Yu, H., Wu, L., et al. (2014). The microbial gene diversity along an elevation gradient of the Tibetan grassland. ISME J. 8, 430-440. doi: 10.1038/ismej.2013.146

Ye, F., and Li, Y. (2009). Enhancement of nitrogen removal in towery hybrid constructed wetland to treat domestic wastewater for small rural communities. Ecol. Engin. 35, 1043-1050. doi: 10.1016/j.ecoleng.2009.03.009

Zhang, D. Q., Jinadasa, K., Gersberg, R. M., Liu, Y., Ng, W. J., and Tan, S. K. (2014). Application of constructed wetlands for wastewater treatment in developing countries-a review of recent developments (2000-2013). J. Environ. Manage. 141, 116-131. doi: 10.1016/j.jenvman.2014.03.015

Zhao, D.-Y., Luo, J., Zeng, J., Wang, M., Yan, W.-M., Huang, R., et al. (2014). Effects of submerged macrophytes on the abundance and community composition of ammonia-oxidizing prokaryotes in a eutrophic lake. Environ. Sci. Pollut. Res. 21, 389-398. doi: 10.1007/s11356-013-1909-1

Zhi, W., Yuan, L., Ji, G., and He, C. (2015). Enhanced long-term nitrogen removal and its quantitative molecular mechanism in tidal flow constructed wetlands. Environ. Sci. Technol. 49, 4575-4583. doi: 10.1021/acs.est. $5 \mathrm{~b} 00017$

Zhou, J., Deng, Y., Luo, F., He, Z., Tu, Q., and Zhi, X. (2010). Functional molecular ecological networks. mBio 1:e00169-10. doi: 10.1128/mBio.00169-10 
Zhou, J., Deng, Y., Luo, F., He, Z., and Yang, Y. (2011). Phylogenetic molecular ecological network of soil microbial communities in response to elevated $\mathrm{CO} 2$. mBio 2:e00122-11. doi: 10.1128/mBio.00122-11

Zhou, L.-J., Ying, G.-G., Liu, S., Zhang, R.-Q., Lai, H.-J., Chen, Z.-F., et al. (2013). Excretion masses and environmental occurrence of antibiotics in typical swine and dairy cattle farms in China. Sci. Total Environ. 444, 183-195. doi: 10.1016/ j.scitotenv.2012.11.087

Zhu, G., Wang, S., Zhou, L., Wang, Y., Zhao, S., Xia, C., et al. (2015). Ubiquitous anaerobic ammonium oxidation in inland waters of China: an overlooked nitrous oxide mitigation process. Sci. Rep. 5:17306. doi: 10.1038/srep 17306
Conflict of Interest Statement: The authors declare that the research was conducted in the absence of any commercial or financial relationships that could be construed as a potential conflict of interest.

Copyright $\odot 2017$ Sun, Liu, Xu, Wu, Zhuang, Deng, Wu and Zhuang. This is an open-access article distributed under the terms of the Creative Commons Attribution License (CC BY). The use, distribution or reproduction in other forums is permitted, provided the original author(s) or licensor are credited and that the original publication in this journal is cited, in accordance with accepted academic practice. No use, distribution or reproduction is permitted which does not comply with these terms. 